Vol. 5, Issue.1, Jan-Feb 2022, page no. 42-63

To cite this article: Dr. Jannifer H. Sykes (2022). THE IMPACT OF NATIONAL BOARD CERTIFICATION, ADVANCED DEGREE, AND TEACHING EXPERIENCE ON READING ACHIEVEMENT OF SECOND AND THIRD GRADE STUDENTS, International Journal of Education and Social Science Research (IJESSR) 5 (1): $42-63$

\title{
THE IMPACT OF NATIONAL BOARD CERTIFICATION, ADVANCED DEGREE, AND TEACHING EXPERIENCE ON READING ACHIEVEMENT OF SECOND AND THIRD GRADE STUDENTS
}

\author{
Dr. Jannifer H. Sykes \\ Elizabeth City State University \\ Elizabeth City, North Carolina, United States \\ DOI: http://dx.doi.org/10.37500/JJESSR.2022.5105
}

\begin{abstract}
The purpose of this paper is to examine the relationship between second and third grade students' reading levels and proficiency scores and their teachers' National Board Certification status. A quantitative correlation design was chosen to address the problem through an examination of the North Carolina reading diagnostic test results of elementary second and third grade students. The analysis included a series of ordinal regressions with either proficiency scores or reading levels as the responses and combinations of teacher certification and years of experience as the predictors. School was factored in as a random effect. Results showed a teacher's years of experience combined with an advanced degree and certification status were significant. The overall results revealed the teacher's school played a significant role as a random effect and when the school was significant, National Board Certification had a significant effect on reading levels. Advanced degree status teachers showed a significant effect with reading levels, using schools as the random effect, but showed a slight significance in proficiency scores. This research could be extended to more subjects, such as math, to determine whether similar trends exist. Overall, results of this study revealed some substantial correlations.
\end{abstract}

KEYWORDS: National Board Certification, Advanced Degree certification, Teacher Years of Experience, No Child Left Behind, Reading 3D, TRC Cutpoints, TRC Proficiency Level Scores

\section{INTRODUCTION}

Every state in the United States establishes a system to regulate teacher certification and has a set of guidelines and procedures for certifying teachers. Equally, all public schools are expected to employ teachers who meet the certification requirements of individual states. No Child Left Behind (NCLB, 2002) was established to provide more school accountability and included the need to hire "highly qualified" teachers to improve the learning outcomes of every student as well as to monitor student achievement (Boyd, Goldhaber, Lankford, \& Wyckoff, 2007). In succession, NCLB requires North Carolina to set specific criteria for a teacher to become "highly qualified." A teacher must obtain a bachelor's degree or higher and hold full certification to teach in the State of North Carolina. A teacher 
must also have a major and coursework that equal to 24 total semester hours in an accredited college for 4 years or in a university with an assigned area of content. In addition, a teacher must hold an advanced degree, National Board Certification, or pass the Praxis in his or her content area (Henry, Thompson, Fortner, Zulli, \& Kershaw, 2010). Comparably, the National Board for Professional Teaching Standards (NBPTS) contends that the best way to bring about improvement and increase the learning outcomes of every student is to improve the quality of teaching. As, board certification is a demanding and detailed undertaking. It includes a four-part written assessment to determine the content area knowledge of candidates. The scripted assessment is compiled in a written portfolio. The electronic six-part assessment exercise can be taken at an assessment center in the national board candidate's state (NBPTS, 2016).

Results of this research can prove to be beneficial to teachers, administrators, parents, and policymakers. These stakeholders can use the results to better understand the effect of National Board Certification on reading achievement in early grades. Therefore, the research could lead to increased support programs for National Board Certification in schools across the state. Furthermore, the funding of advanced degree training in college preparation programs could increase teacher effectiveness. Finally, the North Carolina State Board of Education authorized the use of Read to Achieve (RTA) to target early grade reading proficiency as well as to eliminate social promotion. This study was designed to shed light on the association of reading success to data-driven instruction and the presence of NBCTs in schools across the state.

\section{METHODOLOGY/LITERATURE}

\section{National Board Certification}

According to the U.S. Department of Education (2002), NCLB contained a provision to acquire teachers of high quality to deliver instruction. Likewise, the NBPTS contends that the best way to improve schools and to increase student learning is to strengthen teaching practices in the classroom. Successively, the

NBPTS was established in 1987 (NBPTS, 2015). The NBPTS is a nonprofit, nonpartisan organization that consists of mainly teachers. There are 63 members situated on the board of directors. The primary role of the NBPTS is to improve and strengthen teaching through a three-part mission: (a) create high and rigorous standards for what accomplished teachers should know and be able to do, (b) develop and operate a national voluntary system to assess and certify teachers who meet these standards, and (c) to advance related education reforms for the purpose of improving student learning in America's schools (NBPTS, 2015). The NBPTS operates on a voluntary basis to assess and grant National Board Certification to teachers who meet the criteria set forth by the organization. The NBPTS was established for accomplished teachers. The NBPTS has 25 different certification subject areas, and the standards are adopted to meet each specific certification level (NBPTS, 2016). 
The correlation between National Board Certification and reading instruction began with the development of Literacy Reading-Language Arts Standards for teachers of students ages 3 to 12 with high rigor and tasks to enhance students' learning and social interaction. The NBPTS recognizes the importance of teaching literacy to all learners and understands that every student should become engaged with literacy to understand and appreciate the force of language. For that reason, teachers can earn National Board Certification, which begins with providing evidence of content area knowledge for students ages 3 to 12. The certifications are identified as an Early Childhood Generalist (ages 3 to 8) and Middle Childhood Generalist (ages 7 to 12) certification. The subject matter consists of English language arts standards. The NBPTS acknowledges that students need to apply inquiry learning and higher order thinking skills to problem-solve. Overall, literacy is the gateway to building effective reading, writing, speaking, and listening skills (NBPTS, 2016).

National Board Certification is a highly rigorous process. There is a written assessment containing four sections to determine a teacher's knowledge in his or her assigned content area. The teacher's content area knowledge is presented in a written portfolio. An electronic six-part assessment exercise is also administered in the teacher's assigned content area (NBPTS, 2016). According to Harris and Sass (2008), national board candidates spend approximately 200 to 400 hours completing the written portfolio. In addition, the National Board Certification process is costly, with a $\$ 2,300$ assessment fee.

Harris and Sass (2008) reported that prior to undergoing the National Board Certification, teachers are required to obtain certification from a 4-year college that is regionally accredited, take and pass the teacher licensing exam (Praxis), and hold 3 years of teaching experience (NBPTS, 2015). National Board Certification is valid for 10 years, which means candidates must renew their certification in 8 or 9 years to remain certified (Petty, O’Conner, \& Dagenhart, 2010). For this reason, candidates usually renew their certification 2 years prior to their 10th year to have more than one opportunity to attempt the renewal portfolio process. As a result, the NBPTS offers low interest loans to assist candidates with the cost of the renewal process in North Carolina. In turn, the NBPTS monetary loan assistance for the renewal process enables teachers to enhance their content area knowledge to affect student achievement by making the renewal process affordable for national board candidates.

The NBPTS reported that 467 teachers achieved National Board Certification in North Carolina in the years 2019 through 2020 (Education North Carolina, 2021). In addition, more than 400,000 teachers achieved National Board Certification across the United States since the establishment of NBPTS in 1987.

Correspondingly, 126,000 teachers in 50 states achieved National Board Certification (NCDPI, 2019). According to Klein (2014), Robert Thorpe, the president and CEO of the NBPTS, teachers are more effective in the teaching profession as a result of undergoing the National Board Certification process. Therefore, NBCTs come equipped with the knowledge and skills needed to promote advancements in student learning. 
The Five Core Propositions for Teaching and the NBPTS were developed to positively affect student learning. The Five Core Propositions serve as standards and assessments, and reflect the level of knowledge, skills, abilities, and commitment that accomplished teachers must demonstrate (NBPTS, 2016). The Five Core Propositions are embodied by teachers through their practices and draw on a variety of combinations of skills, applications, and dispositions to promote student learning (NBPTS, 2016).

Therefore, the Five Core Propositions outline what accomplished teachers should know and be able to do.

According to the NBPTS (2016, p. 11), the core propositions are: (a) teachers are committed to students and their learning, (b) teachers know the subjects they teach and how to teach those subjects to students, (c) teachers are responsible for managing and monitoring student learning, (d) teachers think systematically about their practice and learn from experience, and (e) teachers are members of a learning community. All NBCTs in each grade level and subject area take part in their commitment to understanding the Five Core Propositions.

Fowler (2011, p. 4) stated that "for a certification to be useful, it needs a correlation with competence in the thing that it certifies." According to the NBPTS, while teacher licensure systems set the basic requirements to teach in each state, the completion of National Board Certification signifies that teachers have voluntarily gone much further. NBCTs have developed and demonstrated the advanced knowledge, skills, and practices required of an outstanding educator (NBPTS, 2016). The NBPTS further suggested that students of NBCTs surpass those of non-NBCTs in the classroom. In achieving National Board Certification, teachers demonstrate they have the knowledge and skills needed to advance learning to promote student achievement.

Over several years, many changes have occurred regarding board certification within different positions and professions. However, a change that has not occurred is how the public views board certification (Seiler \& Hurwitz, 2010). Thus, board certification remains one of the most important measures of quality for practitioners. The public will probably continue to rely on board certification as a litmus test because the boards have responded to public concerns and addressed them in a highquality way. In 1986, the state medical board started to issue a "time-limited" certificate to ensure physicians maintained their knowledge of the profession during the life of their practice (Seiler \& Hurwitz, 2010). Comparably, the NBPTS requires NBCTs to renew their National Board Certification every 10 years. In this way, the NBPTS can promote continued professional growth for the length of a teacher's career. Thus, every NBCT must renew in his or her content areas. According to Nagin and Conners (2003), specialty areas exist in the field of law that are based on standards and created by a committee of seasoned antitrust and trade regulation lawyers selected by the bar president. These lawyers possess broad and varied experiences to practice regularly in the area of antitrust law, unfair 
methods of competition, and deceptive or unfair trade practices, and possess special knowledge, skills, and proficiency to uphold themselves to the public. Equally, the NBPTS has 25 specialty areas in which candidates can pursue certification. Additionally, the NBPTS has a committee consisting of mainly teachers to establish rigorous professional teaching standards to meet the needs of all students, just as lawyers meet the needs of their clients. The International Standards Organization holds organizations to a certain standard and governs members at different levels. The full body of members voted for important standards to protect the country's products and services. Therefore, it is important to hold organizations to the highest standard to promote positive outcomes. Good college preparation and National Board Certification may continue to promote positive learning outcomes in schools across the nation.

\section{Advanced Degrees}

In the field of higher education, the first teacher education program was implemented at Clark University in 1893. Until then, no outside accredited bodies existed in the field of higher education. However, there are almost 161 universities in the United States that offer doctoral and master degree programs in education and administration. In 1964, the development of the Council for the Advancement of Standards in Higher Education established specific guidelines for master's-level programs. The professional fields offered in higher education included business, social work, engineering, journalism, public administration, and education, with a substantial number of the professional fields offering master's degree programs (Ott, Baca, Cisneros, \& Bates, 2014). In order to earn a master's or doctoral degree in education, an individual must first hold a bachelor's degree. In some states, a teacher is granted advanced degree certification for the duration of his or her practice. Rothman (2009) found earning a master's or doctoral degree in a subject to be an indicator of even higher knowledge in the subject matter to affect student achievement. Moreover, institutions of education offer a master's degree and doctoral degree to emphasize training and experience. The training and experience that occur in method courses and internships enable teachers to overcome the challenges that affect learning in the classroom. Professors of institutions of education are usually required to have years of teaching experience in the public school system and in professional education (Marlow, 2011). Research conducted by Marlow (2011) of master's degrees in education showed that the impact of a

teacher holding a master's degree is mostly felt in the middle or high school levels in North Carolina. In fact, middle and high school students in North Carolina who were taught by a teacher with a master's degree outperformed their peers (i.e., students taught by a teacher of bachelor's degree status) in every subject area.

Although obtaining a master's degree increased student achievement, Arne Duncan, former U.S. Secretary of Education, was strongly opposed to teachers obtaining a master's degree in education. The former U.S. Secretary of Education maintained that measuring an advanced degree teacher's effect on student achievement involves many peripheral factors (Marlow, 2011). These factors may involve 
Vol. 5, Issue.1, Jan-Feb 2022, p no. 42-63

the comparison of students' socioeconomic status and availability of school materials and resources to measure the effectiveness of an advanced degree teacher to a non-advanced degree teacher. (Marlow, 2011).

Conversely, Goldhaber (2002) suggested that a rise in student achievement can determine the impact of an advanced degree on student learning outcomes. According to Vandersall, Vruwink, and Lavenia (2012), districts are investing more in the cost of tuition and increases in salary of advanced degree teachers to develop a more educated workforce. An increase in salary and securing the cost of teacher tuition enables districts to retain a more educated workforce to affect student achievement. Similar to advanced degrees, years of teaching experience can also positively affect student achievement.

\section{Teaching Experience}

Many occupations acknowledge an employee's years of experience as an important part of human resource policy, which includes the compensation system, benefits packages, and promotion decisions (Rice, 2010). Similar to advanced degree certification, the notion is that gaining experience over a period of time heightens one's knowledge and skills and increases productivity. When applied to education, the underlying assumption is that teacher experience promotes teacher effectiveness (Rice, 2010). In North Carolina, the experience level of a teacher is measured by full-time work status in a school and more than 6 months in a calendar year to amount to one fiscal year. Therefore, teachers can earn one full year of credit from July 1 through June 30 in the public schools of North Carolina (NCDPI, 2020). According to Ingersoll and Merrill (2010), post-1980 the nation's teachers had a substantial amount of experience, as a mere $17 \%$ of teachers had taught for 5 years or less. Yet, between 2007 and 2008, approximately $28 \%$ of the teachers in the teaching force had 5 years of experience or less. There was still a substantial number of veteran teachers in 2007-2008, with a quarter of all public school teachers having a total of 20 years or more of teaching experience. Moreover, a disproportionate number of novice classroom teachers can usually be found at the high school level in wealthier areas (N. S. Simon \& Johnson, 2013). This is significant because novice teachers typically have less experience, while veteran teachers commonly have more experience, knowledge, and skills to affect student learning in high and low wealth schools.

Huang and Moon (2009) noted that years of teaching experience is connected to the status of certification and is often used as a variable in educational policy and evaluation studies (EPE studies). The rationale behind EPE studies is to validate the effectiveness of teachers with a number of years in the classroom. Goe and Stickler (2008) suggested a teacher's years of experience makes a difference only for the first 5 years of teaching; after 5 years there is a decrease in a teacher's contributions to student achievement (Rice, 2010). Conversely, Clotfelter, Ladd, and Vigdor (2007) suggested that North Carolina teachers lose their effectiveness after 20 years of teaching or more. Yet, in the first few years, teachers experience more than a 50\% gain in effectiveness (Clotfelter et al., 2007). Kosgei, Mise, Odera, and Ayugi (2013) noted that teacher experience has been shown to have a substantial influence on student learning in elementary and upper secondary schools. Teachers with more years 
Vol. 5, Issue.1, Jan-Feb 2022, p no. 42-63

of experience have greater background experience to enhance learning in the classroom. In addition, a teacher's years of experience can bring more innovative teaching to promote student achievement.

Similarly, Gibbons et al. (1999) revealed that students taught by teachers with more years of experience perform at a higher level. Teachers with more experience have mastered the content and acquired classroom management skills to address the various problems that can occur in the classroom.

Furthermore, teachers with more years of experience possess the content knowledge to teach students of different abilities and backgrounds (Springfield \& Teddlie, 1991). In a well-known study of teacher experience in Tennessee, Huang and Moon (2009) found statistically significant positive results of teacher experience. The researchers used multilevel modeling to measure the effectiveness of the teacher and the

school using the oral reading fluency of second grade readers. However, the study yielded no significant results for first and third grade students. In contrast, beginning teachers with little or no experience made more gains in student reading achievement than teachers with 3 years of teaching experience (Huang \& Moon, 2009). Huang and Moon suggested that among the resources in a school, good preparation, expertise, and teachers with experience are the most dominating factors in student achievement. In addition, the state's school districts at the elementary and secondary level showed years of teaching experience with certification status, academic background, and preparation were the key factors in increasing student achievement (Krasnoff, 2008).

\section{Reading Instruction}

The National Institute of Child and Human Development collaborated with the U.S. Department of Education to establish the National Reading Panel (NRP) in 1997. The NRP was formed to assess existing research into the best teaching practices for reading instruction in young children (National Institute of Child and Human Development, 2006). The panel comprised members of various backgrounds, which included school administrators, teachers in their current practice, and scientists who solely engaged in reading research. The 14 panel members completed their research and submitted their final report in the year 2000. The panel found and submitted a combination of effective techniques to teach children to read, including phonemic awareness, phonics, fluency, guided oral reading, teaching vocabulary, and reading comprehension. The NRP's findings were highlighted in President George Bush's plan for improving education in NCLB, signed in 2001 (National Institute of Child and Human Development, 2006).

Similarly, the U.S. Department of Education and Health and Human Services commissioned the National Research Council to research the prevention of reading difficulties. The National Research Council released a seminal report entitled, Preventing Reading Difficulties in Young Children, nearly 15 years ago (Duke \& Block, 2012). This report provided research-based recommendations to better prepare pre- kindergarten through third grade students to be successful in fourth grade and beyond. 
The report outlined recommendations such as the need for greater access to kindergarten and ways to improve students' word reading skills. Similarly, the report called for attention be given to vocabulary and comprehension skills, comprehension strategies, and conceptual and content knowledge. These recommendations had been long ignored in the early grades, as reported by the National Research Council. As a result, fourth grade students were almost at a standstill in reading comprehension (Duke \& Block, 2012)

Duke and Block (2012, p. 37) outlined the key problems that prevented the adoption of best teaching practices in teaching reading: (a) long-term instruction and instructional reform that occurred at the cost of decreasing vocabulary usage, (b) a lack of conceptual and content knowledge and reading comprehension strategies, (c) a lack of highly effective teachers to teach complex reading skills, (d) minimal time in the regular school day and year, and (e) relying on unreal expectations for children. In contrast, the implication of the best literacy practices implemented by highly effective teachers, as outlined in the NRPR, revealed effective teachers helped to improve struggling readers along racial and ethnic lines. Therefore, highly qualified teachers who are equipped with research-based tools for reading assessment and instruction can positively affect reading achievement (Duke \& Block, 2012). The key to adapting best practices in teaching reading is to avoid the key reading problems noted above for daily reading instruction.

According to Torgensen, Houston, Rissman, and Kosanovich (2007), kindergarten, first grade, and second grade students are in the early development stages of reading. However, students in third grade and higher apply more reading strategies to comprehend a text. Although students in third grade apply higher reading strategies, such as comprehension skills, third grade reading comes to a halt after second grade, which means students lack growth in reading after third grade. As a result, Torgensen et al. found similar reading techniques to yield effective teaching for second and third grade students, including phonics/word analysis, fluency, vocabulary study, and reading comprehension. Comparably, Torgensen et al. noted that the NRP suggested effective reading methods must include word analysis, fluency, vocabulary study, and reading comprehension. In succession, high quality teachers must deliver high quality reading instruction using these reading techniques in the classroom.

According to Fountas and Pinnell (1996), a research-based approach to differentiated teaching support of students in developing reading proficiency in small group reading instruction is known as guided reading. Guided oral reading was also outlined in the NRP's report as an effective technique to teach reading. This

system of strategic activities for proficient reading provides a platform for reading, talking, and occasionally writing to engage with a variety of fiction and nonfiction text. Yet, teachers need a methodical assessment to determine the strengths and needs of students in order to group students for efficient reading instruction (Fountas \& Pinnell, 1996). For that reason, reading assessments are needed to answer critical questions regarding students' reading behaviors. Formative reading 
assessments are required in a substantial number of states. Moreover, the majority of states now require an end-of-year formative assessment in reading for all students starting in third grade. These particular tests usually assess a student's ability to comprehend a text in ways that are outlined by the state's literacy standards (Fountas \& Pinnell, 1996). Concurrently, some states have passed legislation to improve reading in the nation's schools. Many of the NRP's recommendations for cultivating reading in young children are at forefront of public school education. In North Carolina, important legislation was passed to affect young children in reading.

\section{North Carolina's Read to Achieve Legislation and Diagnostic Reading Test}

In response to the NCLB legislation, another legislative initiative was passed in North Carolina known as the Read to Achieve Law (RTA) in 2012 to help young children succeed in reading as part of the Excellent Public Schools Act (NCDPI, 2015). Under this state law, third grade students who are not reading at grade level by the end of third grade will receive special help, which includes summer reading camp and other reading interventions to ensure they can read well enough to perform proficiently in fourth grade. The RTA test is administered at the end of summer camp and once during the school term for third graders who do not master the RTA test during the summer camp school session. Third grade students who do not master the RTA test or qualify for an exemption will be placed in a fourth grade transition classroom where they will receive intense literacy intervention. The primary purpose of the RTA is to ensure that every child can read at or above grade level by the end of third grade (NCDPI, 2015).

A component of the North Carolina RTA is Reading 3D, a diagnostic reading test that is administered by teachers in North Carolina at different administration periods. This reading diagnostic test is also known as the Text Reading Comprehension (TRC) assessment. The purpose of the reading diagnostic test is to follow the progression of text levels across grades and administration periods (Amplify Education, 2014). For the purpose of the current study, the researcher only examined the effect of teachers having National Board Certification, advanced degrees, and varying years of teaching experience at the beginning of the year and the end of the year using student diagnostic reading test results.

TRC cutpoints is a standard-setting procedure appropriate for use with performance-based assessments that yield the categorical text level results of the TRC assessment. The TRC cutpoints are reflective of expectations for students at the respective times of the year (i.e., beginning of the year, middle of the year, and end of the year). The following proficient levels were established to correspond with respective book levels: far below proficient, below proficient, proficient, and above proficient (Amplify Education, 2014). Students who reach their cutpoint are classified as proficient or above proficient, students who fail to meet their cutpoint are classified as far below proficient or below proficient, and students in kindergarten through fifth grade are considered as below grade level when cutpoints are not met. However, in some instances, students who move to the next book level show 
progression in reading levels but lack the proficiency score to satisfy specific TRC cutpoints. The TRC cutpoints are crucial in determining whether a student is reading grade level appropriate text.

The State Budget Act supports the use of formative and diagnostic assessment to measure reading proficiency to fund RTA (NCDPI, 2015). Furthermore, there are two components to help children in kindergarten through third grade to become proficient readers: Dynamic Indicators of Basic Early Literacy Skills (DIBELS) and Reading 3D (diagnostic reading test). Each component provides electronic data to identify the root causes of reading development deficiencies. Teachers work toward helping students to meet their benchmark target. Leveled benchmark books are provided by the NCDPI. Conducting benchmark testing through Reading 3D helps teachers to develop and sustain reading comprehension skills for successful reading for students. Teachers use reading levels to develop corresponding progress monitoring rates in kindergarten through third grade to guide and inform effective instruction (NCDPI, 2015). Instructional supports and services for difficulties in reading development are made available electronically to kindergarten through third grade teachers (NCDPI, 2015). In addition, North Carolina

RTA upholds the accountability in reading in kindergarten through third grade. Likewise, NCLB measures student achievement and holds teachers and schools accountable for student test scores.

The public schools of North Carolina showed more growth on the National Assessment of Education Progress (NAEP) during the 1990s than any state in the country. Shanahan (2005) described the 1990s as the dark shadows that lay across the land of reading education. Some educational pundits viewed literacy education as sufficient, while others raged a reading war to bring about reading reforms. However, by the 21 st century, North Carolina's progress changed tremendously. The latest NAEP showed fourth and eighth grade students lagged behind their peers in reading as reported in 2007. Additionally, between 2008 and 2009, less than two-thirds of third and eighth grade students in North Carolina showed proficiency in reading. Among students who lived in poverty, fewer than half were proficient in both reading and math. North Carolina high school students passed fewer than threequarters of their end-of course examinations and a similar percentage of high school students graduated (Henry et al., 2010).

Henry et al. (2010) reported that for the past decade the North Carolina General Assembly, the governor, the State Board of Education, the courts, and the University of North Carolina have searched for ways to ratify the slow progress and consistent lack of equality in student learning. For that reason, North Carolina policymakers placed increased pressure and gave support for low performing schools, and escalated funds for low performing schools and disadvantaged districts and boosted demands for accountability.

Effect of National Board Certification, Advanced Degrees, and Teaching Experience on Reading Instruction 
According to the NBPTS (2016), accomplished reading-language arts teachers understand the instruction of literacy. Therefore, the NBPTS acknowledges that instruction in literacy includes the intricacy of pedagogy that embodies a universal inventive designed to meet the various literacy needs of every student. This means the NBPTS enables teachers to develop literacy knowledge and skills to help students school- wide to become successful readers. A substantial number of teachers who undergo the national board candidacy tend to describe it as the best professional development they have ever experienced, even if they fail to achieve National Board Certification (Hunzicker, 2011). Moreover, master's degree level teachers who do not obtain National Board Certification can still embed the standards and the Five Core Propositions into their instructional practices (O'Hara \& Pritchard, 2010).

Phillips (2009) found that teachers who go through the National Board Certification process gain more content knowledge to develop effective teaching practices. Moreover, a teacher's content development is an important element of teaching effectiveness, and content development should be prescribed from easy to most difficult and planned at an appropriate level of difficulty to meet the learning needs of every student.

A teacher's national board assessments have been found to predict a student's value-added achievement on state tests. In fact, Hollandsworth (2006) examined the effect of NBCTs and nonNBCTs to compare scores in literacy and math. The study included variables such as gender, race, educational background, licensure areas, endorsements, and experience levels to make the case for a significant difference in student reading and language arts when comparing students taught by NBCTs to those taught by non-NBCTs.

Hollandsworth found that NBCTs between 41 and 50 years of age affected the difference in the national board assessment results. Also, NBCTs between 41 and 50 years of age scored significantly higher than non-NBCTs. In stark similarly, Salvador and Baxter (2010) reported NBCTs who earned English language arts early adolescence certification performed slightly better than non-NBCTs, although NBCTs with English language arts early adolescence certification were not more effective than NBCTs with the middle childhood literacy certification.

North Carolina continues to have the highest number of teachers with National Board Certification among the 50 states. The implication of National Board Certification for reading instruction is literacy teachers apply their content knowledge of the processes of English language arts; reading, writing, listening, speaking, and viewing; and come better equipped to understand how to teach literacy to students. In fact, studies conducted on the impact of National Board Certification on retention rates showed NBCTs have a significant longevity rate compared to non-NBCTs (Goldhaber \& Hansen, 2007). Goldhaber and Hansen (2007) also revealed that NBCTs had a positive effect on student achievement school-wide as more NBCTs were added to the school staff. However, Goldhaber and 
Hansen reported reading gains in third through fifth grade, but NBCTs had an insignificant impact on the literacy gains in kindergarten through second grade.

In terms of the effect of teachers holding an advanced degree on reading achievement, early-childhood educators with a bachelor's degree tend to be more responsive to children and use more activities in language development and emergent literacy to give added value. Reading research revealed that a bachelor's degree alone is insufficient to ensure teacher quality at the early-childhood level (Hightower et al., 2011). Instead, the presence of a bachelor's degree in combination with specialized training related to classroom practice results in quantifiable teacher quality improvements (Hightower et al., 2011).

Proponents of higher education found that a vast number of students in North Carolina with higher math and reading scores were taught by teachers with master's degrees than those without master's degrees.

Therefore, a teacher holding a master's degree was found to be equally as effective as a teacher with more experience than teachers not holding a master's degree (Darling-Hammond, 2000). The reading research has shown a consistent positive correlation between years of teaching experience and higher student achievement. Therefore, reading research emphasizes the importance of teacher certification status, advanced degree, and years of teaching experience to give value added contributions to student achievement.

\section{Theoretical Framework}

The performance management theory of action emphasizes the importance of a teacher's educational background to give value-added contributions to student achievement based on standardized test scores. Bandura's (1978) self-efficacy theory demonstrates teachers' ability to influence student learning behaviors and set goals and expectations for themselves to contribute to student achievement. The performance management theory of action emphasizes the teacher's educational background as value- added contribution to student achievement by way of student performance on standardized tests. According to research, students and highly effective teachers translate into better student outcomes with high-stakes testing (Simmons, 2011).

The performance theory of action suggests characteristics of students, practitioners, and communities with a history of linguistics, racial, and cultural backgrounds are major influences on teacher effectiveness. The teachers in the current study held bachelor's and master's degrees, National Board Certification, and varied years of teaching experience. Master's degree level teachers in this study obtained an advanced degree to become highly effective in their content area to affect student learning. Therefore, the teachers in this study, according to Bandura (1977) and Simmons (2011), seek to apply self-attainment to employ high expectations, advance skills, or a combination of both high expectations 
and advance skills to affect student reading levels in combination with proficiency scores and reading levels.

The quest for effective teachers remains in the forefront of education. Policymakers and educational leaders understand the importance of teacher credentialing to meet accountability demands. Thus, the NBPTS commands the highest level of teaching for students in many disciplines and different developmental stages. Teachers undergo National Board Certification in part to positively affect student achievement. However, much of the research on the impact of National Board Certification on student achievement remains mixed. Throughout the review of literature, no single indicator showed that NBCTs, advanced degree teachers, or teachers with years of experience actually made a high statistically significant difference in the reading scores of second and third grade students.

Shanahan (2005) reported insufficient achievement in reading in most districts across North Carolina. The report revealed that North Carolina is lagging behind in reading. In order for second and third grade readers to become proficient, highly effective teachers should engage students in reading activities that are appropriate for their reading level. In addition, each grade level comes with a prerequisite set of skills that includes phonics, phonemic awareness, reading fluency, guided oral reading, reading comprehension, and vocabulary study. Fountas and Pinnell (1996) gave significant insight into the use of small group reading instruction to accommodate students with various reading levels. However, researchers agree that a formative assessment must take place to determine the specific reading level and behaviors of a student to build upon reading skills and to provide the next teaching step for each student. The NRP pointed out that it is important for highly qualified teachers to understand their students' social and cultural backgrounds to effectively meet their reading needs (Shanahan, 2005).

However, with regard to student achievement, the review of literature showed advanced degree teachers made gains in student achievement in middle school and high school grades and in science and mathematics. The research supports the fact that advanced degree teachers show a higher range of knowledge in the reading content area. According to a study conducted by Rothman (2009), teachers who hold an advanced degree in reading did not contribute much to other subject areas or elementary school level reading. A teacher with 5 years of experience or less did not show a significant effect on student achievement. However, the research revealed that teachers with experience and certification improved the reading scores of second grade students; there was no significant difference for third grade students.

Highly qualified teachers in Goldbaber and Hanson's (2007) study made a significant or no significant impact on second and third grade readers in the study. The researcher provided the methodology and design used to examine the effects of National Board Certification status, advanced degree, and years of teaching experience on the reading achievement of second and third grade students in several districts in northeast North Carolina. 


\section{Data Processing and Analysis}

To test the hypothesis that National Board Certification (primary independent variable) would have an effect on reading scores and reading levels (dependent variables), the researcher applied an ordinal regression analysis using $\mathrm{R}$ for statistical analysis and coding of data. The ordinal regression was used to rank the predictor variables of certification and years of experience, advanced degree and years of experience, and certification and advanced degree. In addition, reading levels were ranked from the lowest reading text level to the highest text level. The reading scores were collected from NBCTs and non- NBCTs. The data collected included the beginning of year and end of year reading scores. The dependent variable of reading score is likely dependent on more than just board certification. Predictor variables, including advanced degrees and years of service, were included in the regression to give a more robust picture of the actual effect of board certification on reading scores (McClendon, 1994). The researcher displayed data results of advanced degree and national board effects in a $2 \times 2$ contingency table. The table analysis was utilized to reveal the independence and dependence between the variables, based on demographic data.

The dispersion of the data occurred in the final stage of the analysis known as the inferential statistical phase. At this point the researcher determined whether a significant correlation existed between the predictor variables and dependent variables using a general linear model and an ordinal regression analysis. The researcher presented and disseminated the findings using a data table.

\section{Limitations and Delimitations}

- This quantitative study included the following limitations:

- The number of participants in the study was limited, given that the research took place in six small, populated schools in a rural area of North Carolina.

- The researcher limited the participants to only second and third grade reading teachers to represent two grade levels involved in diagnostic testing.

- The delimitations that affected the study to some degree were the following:

- The diagnostic reading test was administered exclusively in North Carolina.

- The specialty areas of the NBCTs were limited to Early Childhood (EC) and Middle Childhood (MC) English language arts.

\section{Demographic Data}

The researcher contacted all participants in the study via public school e-mail to obtain participation in the survey. Each teacher was given a URL to answer the four-question closed-ended survey. Each teacher responded to the survey questions. The survey questions were posted electronically on the SurveyMonkey website. The researcher utilized R statistical analysis and coding to examine the survey data. The purpose of the data was to compare the subjects on the ranking of their certification status, degree levels, and years of experience to determine whether there was a significant effect on reading test scores and subsequent reading level based on the demographic characteristics of the teachers. 
Data were collected and examined to determine whether there was a correlation between National Board Certification status and the proficiency scores and reading levels of second and third grade students. The researcher used a simple ordinal regression model to analyze the data, which generated mixed results. The simple regression showed a correlation with school as the random effect and revealed an ample correlation without school as a random effect in the end of year proficiency scores and reading levels, both individually and in combination with National Board Certification. The researcher analyzed advanced degree teachers in combination with NBCTs in proficiency scores and reading levels. Teachers in the study with an advanced degree and National Board Certification showed a significant statistical correlation between proficiency scores and reading levels without school as a random effect. Non-NBCTs showed a statically significant correlation between reading levels with school as a random effect. In contrast, advanced degree teachers showed no significant correlation to proficiency scores. However, all NBCTs, non-NBCTs, and advanced degree teachers showed a significant correlation between proficiency scores and reading levels with years of teaching experience.

Also, years of experience were statistically significant with and without school as a random effect. The results were consistent with the review of literature, which showed master's degree teachers with years of teaching experience affected student achievement. The teacher participants in the current study ranged between 5 and 29 years of experience. The demographic survey results revealed 18 NBCTs, seven non- NBCTs, four non-NBCTs/master's degree teachers, and 11 NBCTs/master's degree teachers participated in the demographic survey. A total of 40 teachers participated in the survey. The number of participants was calculated by the number of certifications they held. Each teacher benchmarked students in reading at the beginning of the year and the end of the year. Several schools participated in the study.

\section{DISCUSSIONS}

This study involved an examination of the effect of National Board Certification status on the reading proficiency scores and reading levels of second and third grade students. The NBPTS enable teachers to pursue national certification that consists of four components: a content knowledge assessment, reflections on student work samples, a classroom video and analysis, and documentation of the teacher's impact on teaching. The participants in the study administered the same test, a state-mandated reading diagnostic test, at the beginning of the year and end of the year. These benchmark reading tests were utilized to determine whether there was a correlation between National Board Certification and the reading scores of second and third grade students. The series of reading tests also measured the hierarchy of reading levels of each student. This state-mandated assessment for kindergarten through third grade is outlined in North Carolina House, Bill 950. Reading 3D is an integral part of House Bill 950. Reading 3D (state's reading assessment) comprises two tests: TRC, and Word Recognition (WR) and Text Reading comprehension that measures students' ability to read and comprehend text. Also, WR is utilized for fluency in sight word recognition. 
For the purpose of this study, the researcher only analyzed text reading comprehension scores (i.e., proficiency scores) and reading level to determine whether there was a correlation between National Board Certification status and students' proficiency scores and reading levels. The leveling system used to level a textbook determines the reading levels of students. The reading levels were measured by a scale of Fountas and Pinnel (1996) for Guided Reading textbook levels A through Z. The textbook levels of A through $\mathrm{Z}$ were revised by Harcourt Rigby, a textbook company.

TRC proficiency scores were ranked as follows: F-far below proficient, BP-below proficient, Pproficient, and AP-above proficient. In addition, the researcher analyzed advanced degree level teachers. The teachers in the study took the added steps to add valued contributions to reading instruction and assessment. The researcher also looked at varying years of experience of NBCTs and advanced degree teachers with school as the random effect. Several schools participated in the study. The study provided valuable data

for NBCTs that may prove to be useful when implementing more rigorous programs to recognize effective reading teachers.

The researcher utilized a quantitative correlational design to collect, analyze, and interpret the data using an ordinal regression. The ordinal regression informed the researcher of the hierarchy of two or more variables to the dependent variable. The researcher used descriptive and inferential statistics to determine whether the null hypotheses could be rejected.

\section{FINDINGS WITHIN THE THEORETICAL FRAMEWORK}

The performance management theory of action suggests disclosing the identity of a teacher's educational background is greatly needed to affect student achievement. A teacher's educational background may help school districts to identify highly qualified teachers to improve student performance outcomes (Simmons, 2011). In this study, the researcher explored NBCTs with advanced degrees, and found a statistically significant correlation to reading achievement. This framework of the study associated postsecondary level status of teachers with student test scores. In the study, NBCTs with an advanced degree level affected the proficiency scores and reading levels of second and third grade students. Similarly, NBCTs with advanced degrees applied their educational backgrounds and self-attainment to affect student performance

outcomes. This study presents an opportunity for state and local school leaders to advocate for the retention of advanced skill reading teachers.

\section{CONCLUSIONS}

Overall, a number of interesting trends and patterns prevailed when comparing all the regression models. When National Board Certification was significant in a model it showed NBCTs made significant growth in the reading levels of second and third grade students, but not proficiency scores. 
However, the significance of these findings is that NBCTs were able to affect struggling readers by raising reading levels, regardless of whether the student was far below proficient or below proficient in the categorical measure of TRC cutpoints. As previously defined by the researcher, TRC cutpoints is a standard setting procedure appropriate for use with performance-based assessments that yields four categorical results (i.e., far below proficient, below proficient, proficient, and above proficient) for a diagnostic reading test known as TRC (Amplify Education, 2014).

Advanced degree teachers also seemed to have an overall effect on the reading levels of second and third grade students when the random effect of school was added. This means some schools had an overall greater number of advanced degree or NBCTs or a combination of the two. Moreover, years of experience of NBCTs, advanced degree, and bachelor's degree teachers had a statistically significant difference for every model except end of year proficiency scores. These results revealed NBCTs, advanced degree, and bachelor's degree teachers aided second and third grade students in mastering specific TRC cutpoints. The students not only read at or above proficiency, they also read on grade level. Therefore, it seems that a teacher's years of experience had a significant effect on a student's overall reading performance. Overall, NBCTs and advanced degree teachers raised the reading levels of their students. The TRC cutpoints revealed students in the study who were far below proficient or below proficient showed an increase in their reading levels. Many extraneous variables affected the results, such as relatively small class sizes that ranged from 11 to 29 students. Also, the rural area in which the schools are located has small, populated counties and schools, which could have adversely affected the outcomes of the study due to small class sizes. Therefore, the implications drawn from this study must viewed as preliminary, which means further validation will be needed through additional research with the use of larger schools.

As far as teacher demographics, there was not a significant difference in the average number of years of experience between board certified and non-board-certified teachers. There also was not a significant relationship between having an advanced degree and a teacher's certification status. However, the mean years of teaching of a non-advanced degree holder were significantly higher than the mean years of an advanced degree holder. This result is what one would expect given that being in school longer decreases the time an individual is out in the workforce. Some schools had more NBCTs and master's degree teachers than other schools in the study. This means some schools had an overall greater number of advanced degree teachers, NBCTs, or a combination of the two at their schools, which translated into higher reading levels.

Further analysis of this topic could include using proficiency scores as another predictor when reading levels are the response and similarly using reading levels as a predictor when proficiency scores are the response. This suggestion could help control a student's performance from being affected by the reading level or similarly the reading level from being affected by performance. Overall, this research study revealed some interesting relationships, but more data and analysis would aid in a greater understanding and more conclusive results. 
Vol. 5, Issue.1, Jan-Feb 2022, p no. 42-63

\section{REFERENCES}

Amplify Education. (2014). mClass: Reading 3D-text reading comprehension: Setting cutpoints for the AmplifyAtlas book set. Retrieved from https://www.amplify.com /assets/pdf/mCLASS_Reading3D_TRC_CutPoints_A.pdf

Bandura, A. (1977). Self-efficacy: Toward a unifying theory of behavioral change. Psychological Review, 84(2), 191-215.

Bandura, A. (1978). Reflections on self-efficacy. In S. Rachman (Ed.), Advances in behavior research and therapy

(Vol. 1, pp. 237-269). Oxford, England: Pergamon.

Boyd, D., Goldhaber, D., Lankford, H., \& Wyckoff, J. (2007). The effect of certification and preparation on teacherquality. The Future of Children, 17(1), 45-68. R2

Clotfelter, C. T., Ladd, H. F., \& Vigdor, J. L. (2007). Teacher credentials and student achievement: Longitudinalanalysis with student fixed effects. Economics of Education Review, 26(6), 673-682.

Darling-Hammond, L. (2000). Teacher quality and student achievement: A review of state policy evidence.

Education Policy Analysis Archives, 8(1), 31.

Duke, N. K., \& Block, M. K. (2012). Improving reading in the primary grades. The Future of Children, 22(2), 37.

Education North Carolina. (2021). NC continues to lead in national board-certified teachers. Retrievedfromhttps://www.ednc.org/nc-continues-to-lead-in-nationalboard-certified-teachers/

Fountas, I. C., \& Pinnell, G. S. (1996). Guided reading: Good first teaching for all children. Portsmouth, NH:Heinemann.

Fowler, M. (2011). Certification, competence and correlation. Retrieved from http://martinfowler.com/bliki/CertificationCompetenceCorrelation.html

Gibbons, M., Limoges, C., Nowotny, H., Schwartzman, S., Scott, P., \& Trow, M. (1999). The new production ofknowledge. London, England: Sage. 
Vol. 5, Issue.1, Jan-Feb 2022, p no. 42-63

Goe, L., \& Stickler, L. M. (2008). Teacher quality and student achievement: Making the most of recent research.

Washington, DC: National Comprehensive Center for Teacher Quality.

Goldhaber, D. D., \& Hansen, M. (2007). National Board Certification and teacher career path: Does NBPTS certification influence how long teachers remain in the profession and where they teach? Seattle, WA:Center on Reinventing Public Education, University of Washington.

Harris, D. N., \& Sass, T. R. (2009). The effects of NBPTS-certified teachers on student assessment. Washington,DC: National Center for Analysis of Longitudinal Data in Education Research.

Henry, G. T., Thompson, L. C., Fortner, C. K., Zulli, R. B., \& Kershaw, D. C. (2010). The impact of teacher preparation on student learning in North Carolina public schools. Chapel Hill, NC: The University of North Carolina at Chapel Hill.

Hightower, M. A., Delgado, C. R., Loyd, C. S., Wittenstein, R., Sellers, K., \& Swanson, C. B. (2011). Improvingstudent learning by supporting quality teaching, key issues, effective strategies. Bethesda, MD: EPE Research Center, Editorial Projects in Education. Retrieved from www.edweek.org

Hollandsworth, S. E. (2006). Best practices of National Board Certified teachers and non-board certified teachersin Grades one and two (Doctoral dissertation). Retrieved from Marshall Digital Scholar Theses, Dissertations and Capstones. (Accession No. 1080)

Huang, F., \& Moon, T. (2009). Is experience the best teacher? A multilevel analysis of teacher characteristics and student achievement in low performing schools. Educational Assessment, Evaluation, and Accountability, 21(3), 209-234.

Hunzicker, J. (2011). Teacher learning through national board candidacy: A conceptual model. Teacher EducationQuarterly, 191.

Ingersoll, R., \& Merrill, L. (2010). Who's teaching our children? Educational Leadership, 67(8), $14-20$.

Klein, R. (2014, December 3). More than 4,000 achieve National Board Certification, profession's mark of accomplished teaching. Retrieved from http://www.nbpts.org/newsroom/more-4000-teachers-achieve-national-board certification-profession $\%$ E2\%80\%99s-mark-accomplished

Kosgei, A., Mise, J. K., Odera, O., \& Ayugi, M. E. (2013). Influence of teacher characteristics 
Vol. 5, Issue.1, Jan-Feb 2022, p no. 42-63

on students' academic achievement among secondary schools. Journal of Education and Practice, 4(3).

Krasnoff, B. (2008). Teacher recruitment, induction, and retention. Portland, OR:

Northwest ComprehensiveCenter.

Marlow, E. (2011). The master's degree in education. College Student Journal, 45(4), 847.

McClendon, M. J. (1994). Multiple regression and causal analysis. Itasca, IL: F. E.

Peacock Publishers. Nagin, S., \& Conners, P. (2003). Board certification specialty areas.

The Florida Bar Journal, 77(40), 42. National Board for Professional Teaching Standards.

(2016). Early childhood generalist standards (3rd ed.).

Arlington, VA: Author. Retrieved from www.nbpts.org

National Board for Professional Teaching Standards. (2015). Why certify?

Retrieved from

http://boardcertifiedteachers.org/aboutcertification/why-certify

National Institute of Child and Human Development. (2006). Report of the National Reading Panel: Teaching children to read: An evidence-based assessment of the scientific research literature on reading and itsimplications for reading instruction (NIH Publication No. 004769). Washington, DC: Government Printing Office.

No Child Left Behind Act of 2001, Pub. L. No. 107-110, § 115, Stat. 1425 (2002).

North Carolina Department of Public Instruction. (2015). K-3 literacy livebinder.

Retrieved from http://www.livebinders.com/play/play/850102

North Carolina Department of Public Instruction. (2020). North Carolina State Board of Education policy manual.

Raleigh, NC: Author.

North Carolina Department of Public Instruction. (2019). NC Remains a Leader in Numbers of National Board-Certified Teachers. Retrieved from

https://www.dpi.nc.gov/news/press-releases/2019/12/10/nc-remains-leader-numbersnational-board-certified-teachers

O'Hara, S., \& Pritchard, R. (2010). Professional degree program for the development of accomplished teachers: Acase for the National Board Certification process. Journal of Educational Research and Practice, 9(10), 54-73. 
Vol. 5, Issue.1, Jan-Feb 2022, p no. 42-63

Ott, M., Baca, E., Cisneros, L., \& Bates, E. (2014). A competency-based approach to the master's degree preparation of higher education professional. Journal of Case Studies in Accreditation and Assessment, 4,1-19.

Petty, T. M., O’Connor, K. A., \& Dagenhart, D. B. (2010). Was it worth it? Some national boardcertified teacherssay no! The Educational Forum, 74(1), 19.

Phillips, A. D. (2009). What do they have that I don't have? Characteristics of National BoardCertified teachers.

Journal of Physical Education, Recreation \& Dance, 80(2), 44-47.

Rice, J. K. (2010). The impact of teacher experience: Examining the evidence and policy implications. Washington,DC: The Urban Institute.

Rothman, R. (Ed.). (2009). Does highly qualified mean highly effective? Alexandria, VA: National School Boards Association.

Salvador, S. A., \& Baxter, A. (2010). National Board Certification: Impact on teacher effectiveness. Charlotte, NC:Center for Research \& Evaluation Office of Accountability.

Seiler, J. G., \& Hurwitz, S. (2010). Board certification: Important and changing. Journal of Hand Surgery, 35(4),663-664.

Shanahan, T. (2005). The National Reading Panel report: Practical advice for teachers (NRP Publication No.

ED489535). Naperville, IL: North Central Regional Educational Laboratory.

Simmons, W. (2011). Effective teaching as a civil right. What will it take to end inequities in access to effectiveteaching? Providence, RI: Annenberg Institute for School Reform.

Simon, N. S., \& Johnson, S. M. (2013). Teacher turnover in high-poverty schools: What we know and can do.

Retrieved from http://isites.harvard.edu/fs/docs

/icb.topic1231814.files/Teacher\%20Turnover\%20in\%20High-Poverty\%20Schools.pdf

Springfield, S., \& Teddlie, C. (1991). Observers as predictors of schools' multi-year outlier status. ElementarySchool Journal, 91(4), 357-376. 
Torgensen, J., Houston, D., Rissman, L., \& Kosanovich, M. (2007). Teaching all students to read in elementaryschool: A guide for principals. Portsmouth, NH: RMC Research Corporation, Centre on Instruction.

U.S. Department of Education. (2002). No Child Left Behind: Desktop reference. Washington, DC: Office ofElementary and Secondary Education.

Vandersall, K., Vruwink, M., \& Lavenia, K. (2012). Master's degrees and teacher effect: New evidence from stateassessments. Arden, NC: Arroyo Research Services. 